
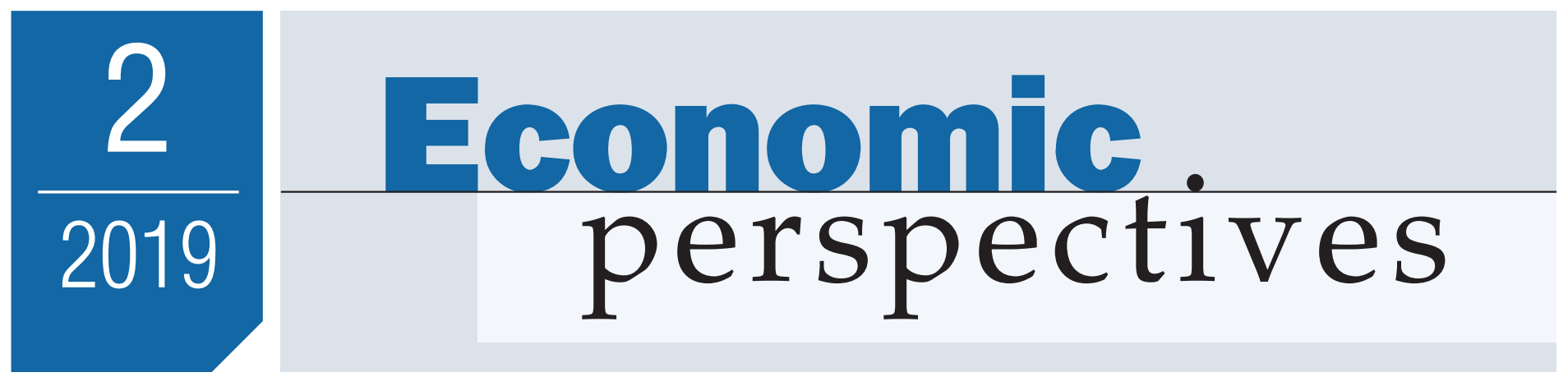

https://doi.org/10.21033/ep-2019-2

\title{
The macroeconomic effects of the 2018 Bipartisan Budget Act
}

\section{Jeffrey R. Campbell, Filippo Ferroni, Jonas D. M. Fisher, and Leonardo Melosi}

\section{Introduction and summary}

In the first quarter of 2018, the Bipartisan Budget Act (BBA) became law. The bill raised the spending caps imposed by the Budget Control Act of 2011 by $\$ 300$ billion for fiscal years 2018 and 2019, in anticipation of a fiscal stimulus that would begin in the second quarter of 2018. While the BBA did not raise government spending immediately after it was signed into law, the private sector might have revised its expectations about future government spending quickly. ${ }^{1}$ As the private sector tries to anticipate the effects of an announced fiscal stimulus, investment and consumption may respond before its implementation. In this article, we use the case of the BBA to provide an empirical assessment of the strength of this mechanism based on the private sector's expectations.

Our analysis relies on a vector autoregressive (VAR) model, which includes fiscal variables along with a number of nonfiscal macroeconomic variables. One of the advantages of VAR models is their extreme flexibility relative to theoretical business cycle models. However, this flexibility bears some cost. Since VAR models are theory free, it is not immediately clear what economic interpretation to give to these models. For instance, VAR models are not specified in terms of structural shocks as theoretical models are (for example, technological shocks or shocks to the monetary and fiscal stance). Nevertheless, it is not unusual for researchers to use VAR models to study the propagation of structural shocks. This is usually done by introducing a minimal set of theoretical restrictions on the VAR parameters and is often called identification of shocks.

The literature on identification of fiscal shocks in VAR models is large. A comprehensive review of the main identification methods and a summary of the existing results can be found in Ramey (2016). A large portion of this literature has emphasized the importance of distinguishing between unexpected fiscal shocks (surprise shocks) and anticipated fiscal shocks (news shocks). Surprise fiscal shocks capture modifications 
to the current fiscal stance that are unanticipated by the private sector and are exogenous (that is, not explained by macroeconomic variables such as gross domestic product [GDP], unemployment, etc.), and they can be identified by the traditional scheme proposed by Blanchard and Perotti (2002). News fiscal shocks correspond to exogenous changes in the future fiscal stance that are announced in advance by policymakers or somehow "anticipated" by the private sector. The characterizing feature of news shocks is that they are learned by the private sector before these shocks actually alter the path of government spending. Even though these shocks do not immediately affect the fiscal fundamentals, they can affect the economy immediately through the adjustment of the private sector's expectations about the future effects of these shocks. The signing of the BBA into law created such a news shock to the future path of government spending. In a later section, we will return to this crucial point.

Economists have employed several methods to identify fiscal news shocks in VAR models. One approach measures the private sector's expectations directly. Ramey (2011) created a series of news about future government spending based on articles published in Business Week and other periodicals. Mertens and Ravn (2012) decomposed Romer and Romer's (2010) narrative tax series into one series in which implementation was within the quarter (unanticipated) and another series in which implementation was delayed (news). Fisher and Peters (2010) created news about government spending by extracting information from stock returns of defense contractors. Ben Zeev and Pappa (2017) identify defense spending news as a shock that 1) is unrelated to current defense spending; and 2) best explains future movements in defense spending over a five-year horizon. Auerbach and Gorodnichenko (2012) construct a continuous forecast series for government spending growth by splicing the Survey of Professional Forecasters (SPF) and the Greenbook forecasts prepared by the Federal Reserve staff for meetings of the Federal Open Market Committee (FOMC). Forni and Gambetti (2016) identify news shocks by imposing a recursive identification scheme with government spending ordered first and survey data that capture the private sector's information about future changes in government spending ordered second.

Our identification approach is similar to that of Forni and Gambetti (2016), as we make use of survey data to measure the private sector's expectations directly and then rely on the definition that the anticipated fiscal shocks are unrelated to the unexpected contemporaneous shock. While they focus on the response of the exchange rate to fiscal shocks (pass-through), we study the broader macroeconomic effects of anticipated fiscal shocks, with particular emphasis on the BBA.

Specifically, we identify anticipated government spending shocks as those shocks that do not affect federal government spending contemporaneously but may influence observed expectations about future government spending. We take expectations about future government spending from the Federal Reserve Bank of Philadelphia's Survey of Professional Forecasters ${ }^{2}$ (SPF), whose participants are asked to express their views about the expected growth rate of real federal government consumption and gross investment over the next four quarters. The contemporaneous response of the other nonfiscal variables in the VAR model (that is, GDP, private consumption, investment, inflation, and the interest rate) is left unrestricted. The adjustment of these variables in anticipation of the actual change in government spending is entirely driven by the revisions of the private sector's expectations.

The magnitude of the BBA shock is then calibrated in such a way that we are able to replicate the revision of the path of the federal spending forecast by the Congressional Budget Office (CBO) after the signing of the BBA. We find that the BBA shock increases GDP growth by 1 percent in 2018 and 60 basis points in 2019; thereafter, the effects on real activity become negligible. Quite interestingly, the fiscal stimulus raises the level of GDP persistently above its trend and there is no payback in GDP growth over the forecast horizon. News about future fiscal stimulus leads to positive co-movement between output, consumption, and investment. Crowding-out effects on private investment become noticeable after a year and a half 
from the realization of the shock. The BBA shock has little impact on inflation. Furthermore, we argue that the size of the BBA shock is fairly big compared with other anticipated fiscal shocks that have hit the U.S. economy since the early 1980s. Since GDP and consumption respond to anticipated government spending shocks before actual government spending adjusts, the private sector's expectations play a nonnegligible role in the propagation of anticipated spending shocks.

In the next section, we introduce the VAR model we use to study the effects of the BBA shock. Then we discuss how we identify the fiscal news shock and the macroeconomic effects of BBA. Next, we analyze the size of the identified BBA shock relative to historical realizations of spending news shocks. We also discuss some of the shortcomings of our analysis. Finally, we present our conclusions and suggest directions for future research.

\section{A VAR model for studying the effects of fiscal policy}

Vector autoregressive (VAR) models have become an important tool for empirical macroeconomic research. On the one hand, VAR models can be regarded as theory-free representations of the data that summarize regular features and facilitate forecasting. On the other hand, many theoretical economic models, such as linearized dynamic stochastic general equilibrium (DSGE) models, lead to (approximate) vector autoregressive representations of the data, making it possible to give some economic interpretation to a VAR model. A VAR model can be represented as follows:

$$
Y_{t}=\Phi_{0}+\sum_{l=1}^{p} \Phi_{l} Y_{t-1}+u_{t}
$$

where $Y_{t}$ is the $N \times 1$ vector of observable time series, $\Phi_{l}, l=1, \ldots, p$ denote the matrices of autoregressive parameters, and $u_{t}$ is the $N \times 1$ vector of reduced form shocks, which are assumed to be serially independent and normally distributed with variance and covariance $\Sigma_{u}$.

Our VAR model includes real GDP, real personal consumption expenditures, real gross private domestic investment, inflation as measured by the GDP deflator, the one-year Treasury bill yield at constant maturity,

\section{FIGURE 1}

Growth of real federal government consumption and gross investment

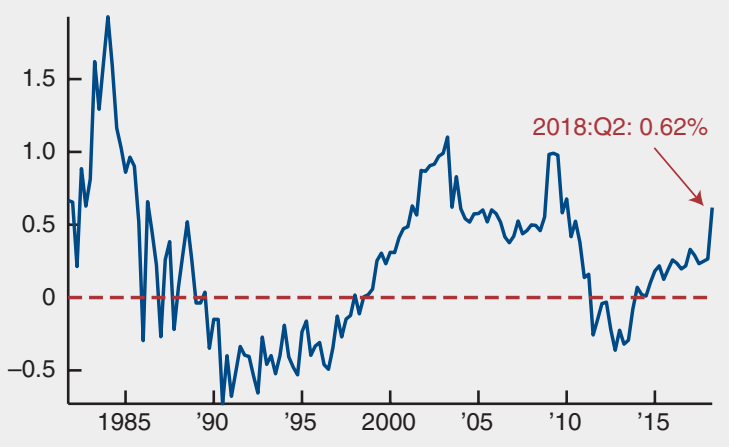

Note: Expected growth rate over the next four quarters. Source: Survey of Professional Forecasters. and a measure of fiscal policy (that is, real federal government consumption expenditures and gross investment). Furthermore, we observe a measure of the expected growth rate of the real federal government consumption and gross investment over the next four quarters. This observable variable is measured by the Survey of Professional Forecasters (SPF) and, as we shall explain in more detail, plays a crucial role in identifying the BBA shock. Figure 1 shows the dynamics of this observable variable over our sample period. All variables are in logs except for the inflation rate and the interest rate. GDP, consumption, investment, and actual government spending are expressed in levels, whereas the expected fiscal variable is expressed in growth rates. The sample period ranges from the fourth quarter of 1981 through the first quarter of 2018. We consider a VAR specification with four lags. 
We estimate the autoregressive parameters and the variance-covariance matrix of the shocks using Bayesian methods. The salient feature of Bayesian analysis is to combine researchers' prior information about the model parameters with the likelihood that the data we observe is generated by the VAR model (likelihood function). The Bayesian approach allows us to tune the prior information about the parameters in order to enhance the forecast accuracy of the VAR model. ${ }^{3}$

\section{Identifying the BBA's macroeconomic impacts}

For identification purposes, we make two assumptions regarding the introduction of the BBA. First, the private sector learned about the BBA shock only when the agreement was signed into law in the first quarter of 2018. Second, we assume that the BBA did not affect federal spending in the first quarter of 2018. The second assumption is consistent with the fact that after the signing of the BBA, the CBO revised its forecasts about federal government spending for the second quarter of 2018 and left unchanged its forecasts for the first quarter of that year. This revision in the CBO forecasts is shown in figure 2.

\section{FIGURE 2}

Revision of CBO forecasts for real government spending after BBA ( $\$$ in billions)

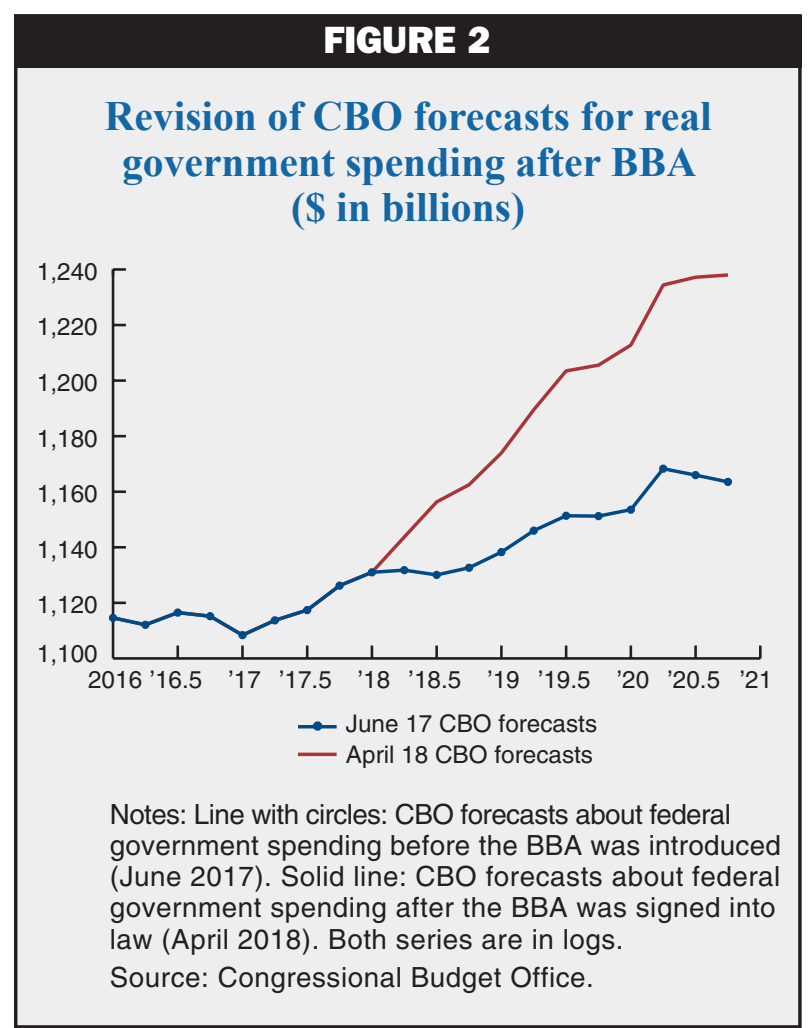

These two assumptions allow us to treat the introduction of the BBA as an anticipated government spending shock that is revealed in the first quarter of 2018 and implemented in the second quarter of 2018. This implies that the BBA shock does not affect government spending contemporaneously, but it does influence immediately the private sector's expectations about future government spending and, potentially, the other nonfiscal variables in the VAR model upon impact. We achieve this identification by ordering the real federal government consumption expenditures and gross investment first and the SPF expectation of its growth rate over the next four quarters second, followed by all the remaining variables. The anticipated fiscal shock is identified as the shock that affects all the variables contemporaneously except for the variable ordered first. ${ }^{4}$ This ordering of the variables implies that the contemporaneous response of the nonfiscal variables (that is, GDP, private consumption, investment, inflation, and the interest rate) to the shock is left unrestricted. It should be noted that the adjustment of these variables in anticipation of the actual change in government

spending is entirely driven by revisions of the private sector's macroeconomic forecasts due to the news shocks. Thus, this ordering of the variables reflects our objective of improving our understanding about the private sector's forward-looking behavior in the aftermath of anticipated fiscal shocks. ${ }^{5}$

To calibrate the magnitude of this shock, we match the VAR-implied response of government spending to the revision of the path for federal government spending forecasted by the $\mathrm{CBO}$ after the signing of the BBA. This revision is shown in figure 2. Given that our fiscal shock is identified using four-quarter-ahead expectations, we match the CBO-forecasted path for government spending only up to 2019:Q1. 


\section{FIGURE 3}

\section{Model forecasts of macroeconomic impact of BBA}
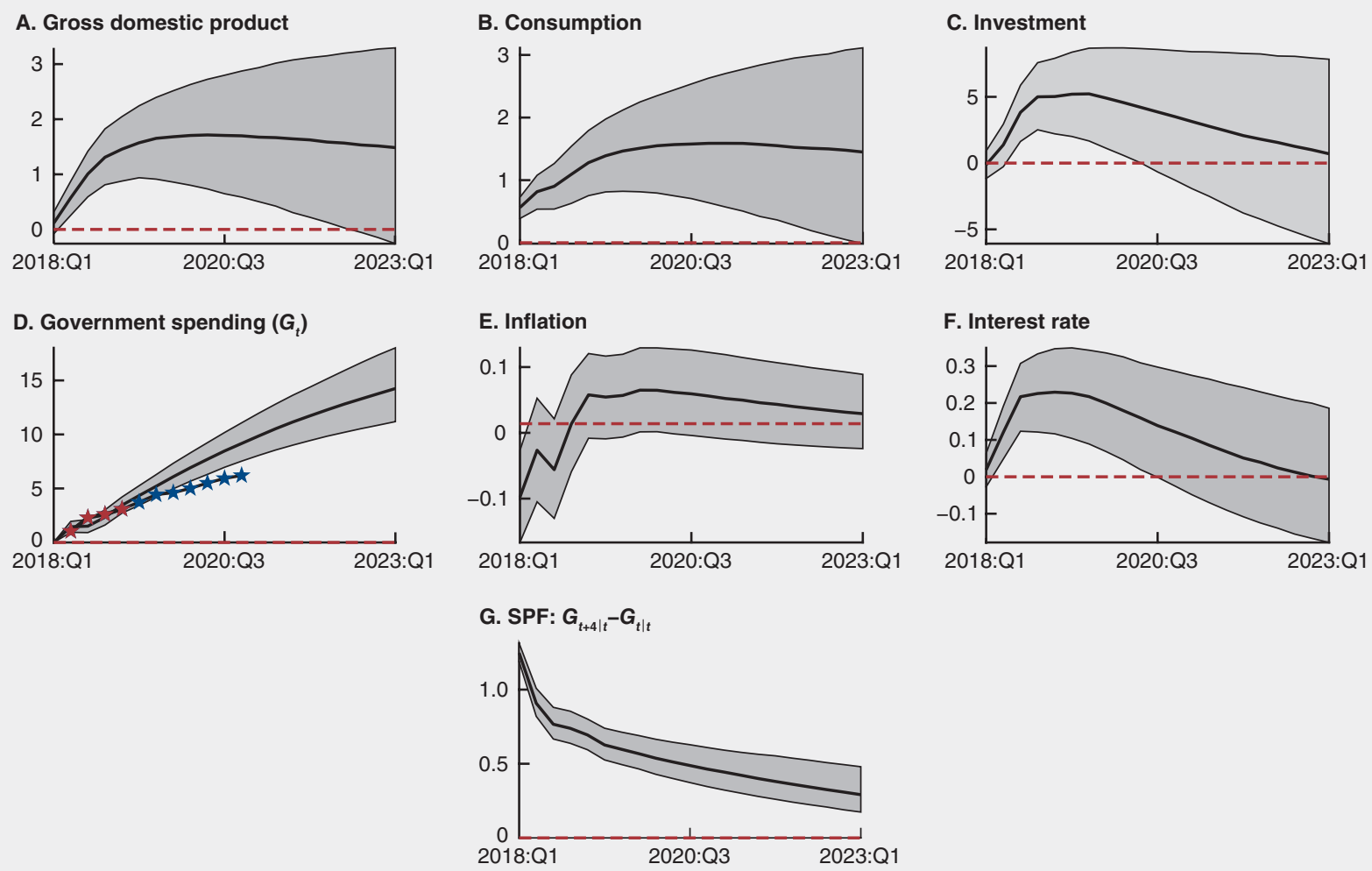

Notes: The solid line denotes the posterior median response of the level of GDP, consumption, investment, federal spending, inflation, interest rate, and the Survey of Professional Forecasters' expectations about the growth rate in federal spending over the next four quarters. Gray areas denote the 60 percent posterior credible sets. The red starred line in panel D denotes the change in the path of federal government spending expected by the CBO from 2018:Q2 through 2019:Q1. The blue starred line in panel D denotes the changes in the CBO path from 2019:Q2 through 2020:Q4. Units: percentage deviations from trend. Sources: Authors' calculations based on data from the Survey of Professional Forecasters and the Congressional Budget Office.

Figure 3 shows the VAR forecasts of the macroeconomic impact of the BBA. The red starred line (panel D) shows the revision in the CBO-expected path of government spending that we aim to match. The blue starred line (panel D) shows the CBO's revision of the forecasts over the medium term (up to the fourth quarter of 2020). The shock raises government spending persistently (panel D). The response of the SPF expectations about future government spending growth is also large and persistent (panel G). GDP, consumption, and investment respond positively to the anticipated fiscal shock (panels A, B, and C). The positive co-movement between output and consumption is not a standard feature of neoclassical models, where an unexpected increase in government spending expands output and generates a decline in consumption. This arises from the large wealth effects operating in these models: An increase in spending makes agents feel poorer because they expect to pay higher taxes in the future to finance the increase in government spending. The higher present value of taxes triggers a negative wealth effect that induces agents to work more and consume less. The increased labor supply lowers the real wage and raises the marginal product of capital in the short run. The rise in the marginal product of capital leads to more investment and capital accumulation. This mechanism, which is at the heart of the real business cycle model (Baxter and King, 1993), is powerful enough to extend to standard New Keynesian models. When the change in government spending is announced to occur in the future, output and hours worked increase when the news about future spending is received, while consumption drops immediately because of the same underlying mechanism (see Mertens and Ravn, 2010). The empirical evidence based on structural VARs suggests instead that consumption increases after 


\section{TABLE 1}

Contribution of BBA to GDP growth, consumption growth, investment growth, and inflation in percentage points

\begin{tabular}{lccccc} 
& $\mathbf{2 0 1 8 : Q 1}$ & $\mathbf{2 0 1 8}$ & $\mathbf{2 0 1 9}$ & $\mathbf{2 0 2 0}$ & $\mathbf{2 0 2 1}$ \\
\hline GDP & 0.11 & 1.01 & 0.64 & 0.05 & -0.06 \\
Consumption & 0.56 & 0.90 & 0.56 & 0.11 & -0.01 \\
Investment & -0.12 & 3.83 & 1.39 & -1.36 & -1.43 \\
Inflation & -0.10 & -0.06 & 0.11 & 0.00 & -0.01
\end{tabular}

Sources: Authors' calculations based on data from the Survey of Professional Forecasters and the Congressional Budget Office.

a government spending shock, regardless of whether it was unexpected or anticipated (see Blanchard and Perotti, 2002; Ben Zeev and Pappa, 2017; and Forni and Gambetti, 2016). To reconcile these opposite views, the literature has proposed two ways to mitigate the strong wealth effect present in standard models so as to generate positive co-movements between output and consumption: the presence of rule-of-thumb or non-Ricardian consumers (see Galí, López-Salido, and Vallés, 2007) and some form of complementarity between private- and public-consumption goods (Fève, Matheron, and Sahuc, 2013).

Investment does not respond immediately after the fiscal news shock arrives and its response seems to be much less persistent than that of consumption and GDP. The rise in GDP that follows the shock leads the Federal Reserve to tighten monetary policy, which is captured by the positive response of interest rates. The VAR model predicts a 1 percentage point hike in the (annualized) short-term interest rate. A tighter monetary policy exerts negative pressure on investment, which after 18 months starts decelerating and reverting back to its trend. This result underscores that crowding-out effects are sizable and start to manifest themselves after 18 months. $^{6}$

It should be noted that consumption responds to the anticipated fiscal shock even before the shock actually raises government spending. This finding lends support to the relevance of the private sector's expectations in the propagation of fiscal news shocks. However, GDP, investment, and interest rates do not respond very much at time 0 to the news shock. In an augmented specification of the VAR where we included net exports over GDP and the log of the trade-weighted exchange rate with advanced economies (not shown here), the dollar appreciates on impact, causing a loss of competitiveness (as in Forni and Gambetti, 2016). This induces a fall in net exports, which compensates for the increase of consumption on impact. Moreover, the fact that output and investment do not move on impact does not imply that the role of the private sector's expectations in the propagation of fiscal news shocks is tiny. To be clear, expectations are at work in every period that follows the arrival time of the fiscal news shock. They may have played a critical role in the response of GDP and the other nonfiscal variables from time 1 and onward. We emphasize the response of macroeconomic variables at time 0 , because in this period nothing except expectations about future fiscal shocks can cause changes to those variables. ${ }^{7}$

Table 1 summarizes the expected contribution of the spending news shock to GDP growth, consumption growth, investment growth, and inflation in 2018, in the following years, and in the quarter of the announcement (2018:Q1). The last time period captures the pure news effects seen in the interval before government spending actually rises and the effects that include the response to the actual spending once it occurs. Most of the effects of the BBA on GDP, consumption, and investment growth are front loaded. The crowding-out effect on private investment is substantial in 2020 and 2021. Inflation falls by less than 6 basis points in 2018 and increases by 11 basis points in $2019 .{ }^{8}$ 


\section{How big is the BBA shock?}

Pretty big, as it turns out. Figure 4 reports the estimated innovations to the professional forecasters' expectations about federal spending over the next four quarters. The black diamond indicates the size of the shock used to simulate the VAR in figure 3. As we explained earlier, the magnitude of this shock was calibrated by using the revision of the path of the CBO's forecasts for federal spending after the signing of the BBA. We note that the magnitude of this shock turns out to be pretty large compared with the estimated innovations to the SPF in the first quarter of 2018 (shown with a blue circle in figure 4).

\section{FIGURE 4}

Estimated innovations to the SPF expectations about federal spending

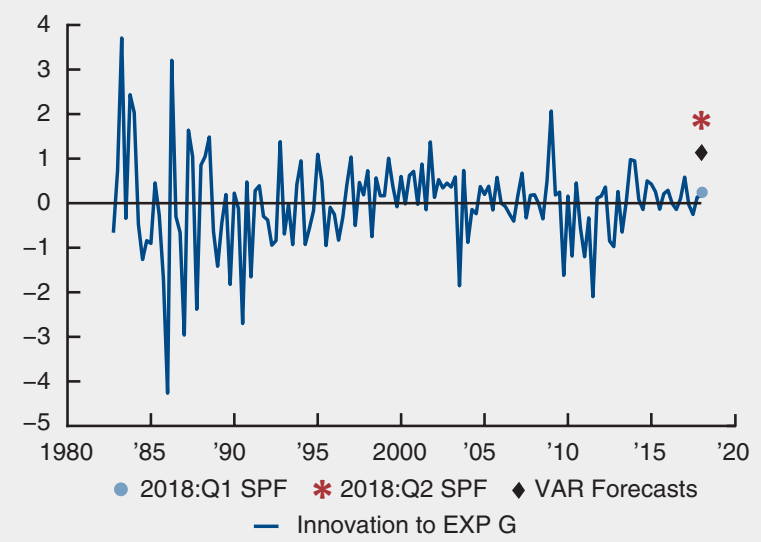

Notes: The solid line denotes the posterior mean estimates of the innovation in the professional forecasters' expectations about the growth rate in federal spending over the next four quarters. The black diamond indicates the size of the shock used to simulate the VAR in figure 3; the blue circle indicates the value of the innovation using the 2018:Q1; the red asterisk indicates the innovation obtained by substituting the 2018:Q1 SPF value with the 2018:Q2 SPF one.

Source: Authors' calculations based on data from the Survey of Professional Forecasters.
Yet, we will argue that the magnitude of this shock is not unrealistically big. Unfortunately, the release of the SPF expectations is not very timely - the BBA was signed into law on February 9, 2018, and the survey was released on the same day. Hence, it is conceivable that many professional forecasters did not include the BBA's approval in their information set when forming their forecasts about future government spending in the first quarter of 2018. Consequently, the revision in expectations is not particularly large in the first quarter. However, the revision in the second quarter is quite substantial, as shown in figure 1. If we substitute the SPF expectations about federal spending over the next four quarters measured in the first quarter of 2018 with the values that we observe in the second quarter of the same year, we obtain a larger shock than the one we used to simulate the VAR. (The magnitude of the shock is marked with a red asterisk in figure 4.) Thus, the size of the shock used for our VAR simulation exercise in figure 3 (black diamond in figure 4) lies in between the magnitude of the innovation obtained when professional forecasters were all aware of the BBA in the second quarter of 2018 (red asterisk in figure 4) and the one estimated for the first quarter of 2018 when they were not (blue circle in figure 4).

\section{Caveats}

Our analysis has a number of caveats. We identify news shocks to government spending using changes in expectations over the next four quarters. However, the BBA will also affect government spending in 2019 and 2020, according to the CBO. The CBO's projections for 2019 and 2020 (blue starred line in figure 3) imply a softer path for government spending than that implied by our VAR model.

Another shortcoming is the lack of synchronization of the variables included in the VAR model. Professional forecasters receive the survey questionnaire after the release of the U.S. Bureau of Economic Analysis's advance report. This report is released at the end of the first month of each quarter. Suppose that the government announces a fiscal intervention in the last month of a quarter. Private expectations about government spending are likely to react in that quarter. However, the SPF data reflect this revision in expectations with a one-quarter delay. This delay could lead to inaccuracy on how spending shocks are identified in the VAR model. 
We define anticipated government spending shocks as those shocks that do not affect government spending contemporaneously while they can influence on impact the observed expectations about future government spending, as well as the other macroeconomic variables in our VAR model. This identification scheme requires that government spending is not influenced contemporaneously by any macroeconomic variables. As we explained earlier, the private sector revises its expectations about future government spending immediately after the BBA is signed into law. This change in expectations affects GDP and the interest rate already in the first quarter of 2018 with potentially immediate feedback on federal spending. Our identification strategy disregards these feedback effects. While this implication of our identification scheme is an issue, in principle, it is worth noting that the response of GDP and the interest rate in the first quarter of 2018 (that is, time 0 on the vertical axis of figure 3 ) is tiny.

The empirical analysis in this article disregards the role of taxes. This is particularly relevant given the tax cut (for example, under the Tax Cuts and Jobs Act of 2017) that took place at the end of 2017, a few months before the introduction of the BBA. If this tax cut were merely responding to cyclical conditions, then our VAR model would implicitly capture their effects. However, it is hard to argue that this was case for 2017 as the economy was expanding at a strong pace. To assess the macroeconomic implications of the recent fiscal stimulus, one has to also take into account the direct effects of tax cuts, as discussed in Mertens (2018), as well as possible anticipation effects, as discussed in Butters and Veracierto (2009) for the 2001 recession.

\section{Conclusion}

We quantify the macroeconomic impact of introducing the BBA using a VAR model. We interpret the signing of the BBA into law as an anticipated government spending shock, which we identify by observing the private sector's expectations about future government spending from the Survey of Professional Forecasters. We calibrate the magnitude of this BBA shock by using the revision of the future expected path of government spending by the $\mathrm{CBO}$ right after the BBA was signed into law. We find a sizable and statistically significant impact on output growth, amounting to a GDP increase of 1 percent in 2018 and 60 basis points in 2019 relative to a counterfactual scenario whereby the BBA was not passed and spending caps were still binding. The VAR model predicts a 1 percentage point hike in the (annualized) short-term interest rate in response to the recent fiscal stimulus. Private consumption and investment also respond positively to the shock. While the response of investment is delayed, consumption responds to the BBA shocks before actual government spending adjusts, suggesting that the private sector's expectations play a role in the propagation of these shocks to the macroeconomy. After six quarters, private investment falls fairly rapidly, suggesting a sizable degree of crowding out.

The impact on inflation is initially negative and then turns positive. However, the response of prices is fairly contained. While this is not the first article to find that prices respond negatively to fiscal shocks, we view this finding as important because it challenges the conventional view of fiscal shocks as demand shocks. This topic is a promising venue for future research.

There are several other interesting directions for research. Our study was limited to the BBA, but one could perform a similar analysis for the Tax Cuts and Jobs Act of 2017 and possibly study the joint effects of these two fiscal measures. 


\section{NOTES}

${ }^{1}$ When we use the term government spending, we refer to federal government consumption expenditures and gross investments from the NIPA (National Income and Product Accounts) tables. However, government spending typically refers to government outlays, which include both government purchases and transfer payments.

${ }^{2}$ Details available online, https:/www.philadelphiafed.org/research-and-data/real-time-center/survey-of-professional-forecasters/.

${ }^{3}$ This feature of the Bayesian analysis mitigates the problem of overfitting, which affects largely parameterized models like our VAR model. We adopt the unit-root prior introduced by Sims and Zha (1998) and choose the direction of the Bayesian shrinkage so as to maximize the marginal likelihood of the VAR model, as suggested by Giannone, Lenza, and Primiceri (2015). The direction of the Bayesian shrinkage is controlled by five hyperparameters that affect each of the following: 1) the prior tightness for the autoregressive coefficients of order one; 2) the prior variance for the autoregressive coefficients of lags higher than one; 3) the weight for the priors for the variance and covariance matrix of innovations; 4) the weight on co-persistence prior dummy observationsthis reflects the belief that when the data are stable at their initial levels, they will tend to persist at that level; and 5) the weight on own-persistence prior dummy observations - this reflects the belief that when a variable has been stable at its initial level, it will tend to persist at that level, regardless of the value of other variables. The prior relies on the first and the second moment of the observable, which are computed using a pre-sample of four quarters. The prior is implemented via dummy observations.

${ }^{4}$ In technical terms, the anticipated fiscal shock is identified by the second shock in the recursive orthogonalization of the estimated variance covariance matrix of the VAR innovations $\Sigma_{u}$. Since the orthogonalization is unique, there is only one shock that triggers contemporaneous changes to all the variables in our VAR model except for real federal government consumption expenditures and gross investment.

${ }^{5}$ This variable ordering also implies that expectations about future government spending do not react to "business cycle" shocks, regardless of their demand or supply origin. Given the countercyclical nature of government spending, one might suspect that the shock that we are isolating could also capture a typical business cycle shock; for example, a shock that lowers output today and generates an upward revision of expectations about future government spending through the countercyclical fiscal stabilizers. While this is a valuable critique, there are two reasons for preferring the recursive identification scheme. First, it has been used in other studies; for example, Forni and Gambetti (2016); therefore, it gives us a direct benchmark comparison. Second, it is not clear that professional forecasters perfectly observe a contemporaneous shock to output given the timing of the SPF questionnaire. Professional forecasters receive the survey questionnaire after the release of the U.S. Bureau of Economic Analysis's advance report. This report is released at the end of the first month of each quarter. They might not have enough information to identify a shock to output and adjust their expectations accordingly. Hence, it seems legitimate to assume that a shock to output does not affect expectations of government spending contemporaneously. However, we also tried to address this issue more explicitly by exploring different alternative identification schemes. The results are comparable to our baseline results and available upon request.

${ }^{6}$ Akin to announced fiscal shocks, unexpected changes in the fiscal stance generate co-movements between output and consumption in our VAR specification. An increase in government spending crowds out investment on impact when it is unexpected; when it is announced to occur in the future, investment declines with a substantial delay. While surprise government spending shocks are deflationary, this is not the case for announced fiscal expansions.

${ }^{7}$ The only period in which singling out the role of beliefs in the propagation of shocks is immediate is time 0 . In that period and only in that period, the responses of all the macroeconomic variables to the fiscal news shock are solely driven by changes in beliefs because fiscal fundamentals will start changing only from time 1 and onward.

${ }^{8}$ The negative response of inflation is consistent with Edelberg, Eichenbaum, and Fisher (1999); Fatás and Mihov (2001); Canova and Pappa (2007); Mountford and Uhlig (2009); Dupor and Li (2015); D’Alessandro, Fella, and Melosi (2018); Jørgensen and Ravn (2018); and Hall and Thapar (2018). 


\section{REFERENCES}

Auerbach, Alan J., and Yuriy Gorodnichenko, 2012, "Measuring the output responses to fiscal policy," American Economic Journal: Economic Policy, Vol. 4, No. 2, May, pp. 1-27. Crossref, https://doi.org/10.1257/ pol.4.2.1

Baxter, Marianne, and Robert G. King, 1993, "Fiscal policy in general equilibrium," American Economic Review, Vol. 83, No. 3, June, pp. 315-334, available online, https://www.jstor.org/ stable/2117521?seq=1\#metadata_info_tab_contents.

Ben Zeev, Nadav, and Evi Pappa, 2017, "Chronicle of a war foretold: The macroeconomic effects of anticipated defence spending shocks," Economic Journal, Vol. 127, No. 603, August, pp. 1568-1597. Crossref, https://doi.org/10.1111/ecoj.12349

Blanchard, Olivier, and Roberto Perotti, 2002, "An empirical characterization of the dynamic effects of changes in government spending and taxes on output," Quarterly Journal of Economics, Vol. 117, No. 4, November, pp. 1329-1368. Crossref, https://doi.org/10.1162/003355302320935043

Butters, R. Andrew, and Marcelo Veracierto, 2009, "Preannounced tax cuts and their potential influence on the 2001 recession," Economic Perspectives, Vol. 33, No. 3, Third Quarter, pp. 17-32, available online, https://www.chicagofed.org/publications/economic-perspectives/2009/3qtr-butters-veracierto.

Canova, Fabio, and Evi Pappa, 2007, "Price differentials in monetary unions: The role of fiscal shocks," Economic Journal, Vol. 117, No. 520, April, pp. 713-737. Crossref, https://doi.org/10.1111/ j.1468-0297.2007.02047.x

D'Alessandro, Antonello, Giulio Fella, and Leonardo Melosi, 2018, "Fiscal stimulus with learning-bydoing," Federal Reserve Bank of Chicago, working paper, No. 2018-09, May. Crossref, https://doi.org/ 10.21033/wp-2018-09

Dupor, Bill, and Rong Li, 2015, "The expected inflation channel of government spending in the postwar U.S.," European Economic Review, Vol. 74, February, pp. 36-56. Crossref, https://doi.org/10.1016/ j.euroecorev.2014.11.004

Edelberg, Wendy, Martin Eichenbaum, and Jonas D. M. Fisher, 1999, "Understanding the effects of a shock to government purchases," Review of Economic Dynamics, Vol. 2, No. 1, January, pp. 166-206. Crossref, https://doi.org/10.1006/redy.1998.0036

Fatás, Antonio, and Ilian Mihov, 2001, "The effects of fiscal policy on consumption and employment: Theory and evidence," Centre for Economic Policy Research, discussion paper, No. 2760, April, available online by subscription, https://cepr.org/active/publications/discussion_papers/dp.php?dpno=2760.

Fève, Patrick, Julien Matheron, and Jean-Guillaume Sahuc, 2013, "A pitfall with estimated DSGEbased government spending multipliers," American Economic Journal: Macroeconomics, Vol. 5, No. 4, October, pp. 141-178. Crossref, https://doi.org/10.1257/mac.5.4.141

Fisher, Jonas D. M., and Ryan Peters, 2010, "Using stock returns to identify government spending shocks," Economic Journal, Vol. 120, No. 544, May, pp. 414-436. Crossref, https://doi.org/ 10.1111/j.1468-0297.2010.02355.x

Forni, Mario, and Luca Gambetti, 2016, "Government spending shocks in open economy VARs," Journal of International Economics, Vol. 99, March, pp. 68-84. Crossref, https://doi.org/10.1016/j.jinteco.2015.11.010 
Galí, Jordi, J. David López-Salido, and Javier Vallés, 2007, "Understanding the effects of government spending on consumption," Journal of the European Economic Association, Vol. 5, No. 1, March, pp. 227-270. Crossref, https://doi.org/10.1162/JEEA.2007.5.1.227

Giannone, Domenico, Michele Lenza, and Giorgio E. Primiceri, 2015, "Prior selection for vector autoregressions," Review of Economics and Statistics, Vol. 97, No. 2, May, pp. 436-451. Crossref, https://doi.org/10.1162/REST_a_00483

Hall, Matthew, and Aditi Thapar, 2018, "The economic effects of government spending: The importance of controlling for anticipated information," mimeo, February, available online, https://sites.google.com/a/ umich.edu/aditi-thapar/home/research.

Jørgensen, Peter L., and Søren H. Ravn, 2018, "The inflation response to government spending shocks: A fiscal price puzzle?," mimeo, July, available online, https://sites.google.com/site/sorenhoveravn/research.

Mertens, Karel, 2018, “The near term growth impact of the Tax Cuts and Jobs Act," Federal Reserve Bank of Dallas, working paper, No. 1803, March 23. Crossref, https://doi.org/10.24149/wp1803

Mertens, Karel, and Morten O. Ravn, 2012, "Empirical evidence on the aggregate effects of anticipated and unanticipated US tax policy shocks," American Economic Journal: Economic Policy, Vol. 4, No. 2, May, pp. 145-181. Crossref, https://doi.org/10.1257/pol.4.2.145

Mertens, Karel, and Morten O. Ravn, 2010, "Measuring the impact of fiscal policy in the face of anticipation: A structural VAR approach," Economic Journal, Vol. 120, No. 544, May, pp. 393-413. Crossref, https://doi.org/10.1111/j.1468-0297.2010.02361.x

Mountford, Andrew, and Harald Uhlig, 2009, "What are the effects of fiscal policy shocks?," Journal of Applied Econometrics, Vol. 24, No. 6, September/October, pp. 960-992. Crossref, https://doi.org/10.1002/ jae.1079

Ramey, Valerie A., 2016, "Macroeconomic shocks and their propagation," in Handbook of Macroeconomics, 11 Vol. 2A, John B. Taylor and Harald Uhlig (eds.), Amsterdam: Elsevier / North-Holland, pp. 71-162. Crossref, https://doi.org/10.1016/bs.hesmac.2016.03.003

Ramey, Valerie A., 2011, "Identifying government spending shocks: It's all in the timing," Quarterly Journal of Economics, Vol. 126, No. 1, February, pp. 1-50. Crossref, https://doi.org/10.1093/qje/qjq008

Romer, Christina D., and David H. Romer, 2010, "The macroeconomic effects of tax changes: Estimates based on a new measure of fiscal shocks," American Economic Review, Vol. 100, No. 3, June, pp. 763-801. Crossref, https://doi.org/10.1257/aer.100.3.763

Sims, Christopher A., and Tao Zha, 1998, "Bayesian methods for dynamic multivariate models," International Economic Review, Vol. 39, No. 4, November, pp. 949-968. Crossref, https://doi.org/10.2307/2527347 
Jeffrey R. Campbell is a senior economist and research advisor, Filippo Ferroni is a policy economist, Jonas D. M. Fisher is a vice president and the director of macroeconomic research, and Leonardo Melosi is a senior economist in the Economic Research Department at the Federal Reserve Bank of Chicago.

\section{2019 Federal Reserve Bank of Chicago}

Economic Perspectives is published by the Economic Research Department of the Federal Reserve Bank of Chicago. The views expressed are the authors' and do not necessarily reflect the views of the Federal Reserve Bank of Chicago or the Federal Reserve System.

Charles L. Evans, President; Anna L. Paulson, Executive Vice President and Director of Research; Daniel G. Sullivan, Executive Vice President, outreach programs; Spencer Krane, Senior Vice President and Senior Research Advisor; Sam Schulhofer-Wohl, Senior Vice President, financial policy; Daniel Aaronson, Vice President, microeconomic policy research; Gene Amromin, Vice President, finance team; Jonas D. M. Fisher, Vice President, macroeconomic policy research; Leslie McGranahan, Vice President, regional research; Marcelo Veracierto, Senior Economist and Economics Editor; Helen Koshy and Han Y. Choi, Editors; Julia Baker, Production Editor; Sheila A. Mangler, Editorial Assistant.

Economic Perspectives articles may be reproduced in whole or in part, provided the articles are not reproduced or distributed for commercial gain and provided the source is appropriately credited. Prior written permission must be obtained for any other reproduction, distribution, republication, or creation of derivative works of Economic Perspectives articles. To request permission, please contact Helen Koshy, senior editor, at 312-322-5830 or email Helen.Koshy@chi.frb.org.

ISSN 0164-0682 